Portland State University

PDXScholar

\title{
The Sino-Russian Embrace: Resiliently Asymmetrical
}

Ryan Donovan

Portland State University

Follow this and additional works at: https://pdxscholar.library.pdx.edu/honorstheses

\section{Let us know how access to this document benefits you.}

\section{Recommended Citation}

Donovan, Ryan, "The Sino-Russian Embrace: Resiliently Asymmetrical" (2018). University Honors Theses. Paper 502.

https://doi.org/10.15760/honors.506

This Thesis is brought to you for free and open access. It has been accepted for inclusion in University Honors Theses by an authorized administrator of PDXScholar. Please contact us if we can make this document more accessible: pdxscholar@pdx.edu. 
The Sino-Russian Embrace: Resiliently Asymmetrical

$$
\text { by }
$$

Ryan Donovan

An undergraduate honors thesis submitted in partial fulfilment of the requirements for the degree of

Bachelor of Arts

in

University Honors

and

Political Science and Russian

Thesis Adviser

Dr. Joshua Eastin

Portland State University 
Since the collapse of the Soviet Union, Sino-Russian relations have gone through an extraordinary renaissance. This paper explores Russia's relationship with China, particularly in Central Asia, through a latticework of global, regional, and bilateral trends, identifying key areas of convergence as well as underlying stresses. Both powers share an uneasiness towards "outside influence" i.e. the U.S. and the EU and have made significant progress in economic trade and institutional development. The relationship, however, faces several factors that if not managed could inhibit future growth. Among potential inhibitors are a deep-rooted historical mistrust and concerns over an increasingly asymmetrical relationship in almost all vital categories for Russia, particularly energy and defense. In addition, while there has been progress in institutional development in Central Asia, there still remains distinct spheres of Russian and Chinese institutions. This paper concludes that although the Sino-Russia relationship has made significant gains in recent years, historical mistrust, diverging concepts of regional integration, compounded by growing concerns in Moscow about the asymmetrical nature of the relationship could inhibit future growth, especially if those weaknesses are effectively exploited by the Trump Administration to drive a wedge between both states. Just to note, this paper uses the terms Russia, Moscow, and the Kremlin interchangeably to represent the Russian leadership. Furthermore, due to an inability to access Chinese-language sources, this paper relies heavily on Western research and analyses of Chinese work.

\section{SINO-RUSSIAN RELATIONSHIP IN-CONTEXT}

As Russian Foreign Minister Lavrov stated in his analysis of Russian Foreign Policy, “...policy cannot be detached from history...”, and as such, to understand 
where the Sino-Russian relationship is today, it is important to look back at the historical foundations on which the contemporary relationship was formed. As both China and Russia are neighbors and have been engaged in Central Asia for hundreds of years, the scope of this historical overview will be limited to the latter half of the twentieth century up to the beginning of the twenty-first century.

Shortly after the founding of the People's Republic of China in 1949, relations between the Soviet Union and the new regime in Beijing quickly deteriorated. Relations were worsened by a personal spat between Chairman Mao and Stalin and his predecessor, Nikita Khrushchev over the role of China in the greater communist movement. This early Sino-Soviet period was marked by limited and strained cooperation during the early foundational years of the People's Republic of China under Mao (Lo 2008). The nascent "fraternal" relationship between the Soviet Union and China heated up quickly as evidenced in a series of violent border incidents in 1969 (Lo 2008). On a strategic level, Moscow and Beijing openly competed for influence in the developing world and among non-aligned states. The border disputes and international competition highlights the perennial problem of trust and prestige, one has plagued the Sino-Soviet and -Russian relationship for centuries. Whether accurate or not, both China, the Soviet Union, and contemporary Russia refuse to be treated as second-tier actors. Furthermore, Moscow chaffed at the idea of Beijing as an equal player in the communist movement and on the international stage. SinoSoviet rapprochement happened precipitously as the Soviet Union could no longer escape internal economic and political malaise, all the while China progressed with market reforms. The spirit of the new relationship is encapsulated in Mikhail Gorbachev's epoch-making Vladivostok Speech, in which he calls for "an atmosphere of good neighborliness" between the two states. This speech was quickly followed up 
by a summit-level meeting in 1989 between Gorbachev and Deng Xiaoping and full normalization of relations.

The newly independent Russian Federation, facing a series of problems that threatened to tear a unified-Russia apart, had a limited capacity to project their influence throughout most of the former-Soviet Union (Kozyulin 2014). With the replacement of the pro-western Foreign Minister Kozyrev with a former KGB director, Yevgeny Primakov, Russian foreign policy took a turn towards Asia. Primakov, a strategic mind shaped by his Cold War service in the KGB, correctly saw Asia and more specifically, China as a rising power that, if managed carefully, could limit U.S. and NATO encroachment into the traditional Russian sphere of influence (Carlsson, Oxenstierna, and Weissmann 2015). It was during this immediate postSoviet period (1992-2001) that trade, specifically in defense systems increased. Defense was a win-win for both, Moscow needed foreign currency to keep its strategic defense industries afloat, and China, under the weight of Western arms sanctions stemming from the Tiananmen Square Massacre, needed to modernize its outmoded military (Carlsson, Oxenstierna, and Weissmann 2015). Growing concerns of NATO enlargement eastward dovetailed with Beijing's antagonistic perceptions of U.S. hegemony on the world stage created the conditions for the signing a strategic partnership in 1996, one that is emphasizes “...equality, mutual confidence, and mutual coordination" (Permanent Representatives of China and the Russian Federation). This strategic partnership laid the groundwork for the "Treaty of Good Neighborly, Cooperative and Friendly Relations” in 2001. The treaty was a major step in formalizing ties. The treaty's first article underscores the basis of the new relationship: "[built on] mutual respect of state sovereignty and territorial integrity, mutual non-aggression, mutual non-interference in each other's internal affairs, equality and mutual benefit and peaceful coexistence. These two bilateral treaties 
represent a new era in Sino-Russian relations formalizing the increasing political and security convergence between the two states.

The brief Post-9/11 period, marked by limited cooperation with the U.S. on counter-terrorism, saw the entrance of the U.S. as an important player in the security of Central Asia. The presence of the U.S. and NATO in the heart of Central Asia challenged Russia's traditional role as guarantor of security in the post-Soviet space, as well as unnerved Beijing with the forward deployment of "foreign forces" so close to the Chinese frontier. While ambivalently supporting the United States in its War on Terror, the Kremlin as with Beijing, perceived the presence of large numbers of American troops stationed in the very heart of Central Asia as a potential strategic threat (Carlsson, Oxenstierna, and Weissmann 2015). Building from progress made in 1990s, this period saw the germination of Russian- and Chinese-led institutions, particularly in Central Asia. The U.S. presence forced Russia to reengage with Central Asian states, while simultaneously China began to capitalize on Central Asian states' pragmatic insistence on avoiding overreliance on Russia. The Kremlin cemented its commitment to its Near Abroad through the Commonwealth of Independent States (CIS), a relatively weak Moscow-centric organization of former-Soviet states. Furthermore, Moscow used its close military-military ties with many former-Soviet states to formalize the CIS Collective Defense Treaty into a so-called 'military alliance', known as the Collective Security Treaty Organization (CSTO). As in Moscow, Beijing, was deeply concerned about a permanent U.S. presence in Central Asia, perceiving it as a further attempt to contain their 'rightful' and 'peaceful' presence in Central Asia (Rydqvist and Hailin 2014). What was especially concerning for Beijing is that its Westernmost frontier (Lanzhou military region) bordering Afghanistan, India, Kyrgyzstan, Pakistan, Russia, and Tajikistan is sparsely defended, with most units being stationed along the eastern coast (Scobell, Ratner 
and Beckley 2014). Further complicating matters, the Bush Administration policy of democracy promotion rubbed against the grain. A wave of revolutions calling for democratic changes, starting in Georgia in 2003 and ending in Kyrgyzstan in 2005, concluded any semblance of timid acquiescence of U.S. forces in the region. The Color Revolutions and the U.S. Invasion of Iraq in 2003 confirmed the Chinese and Russian leaderships' worst fears, that the U.S. was engaged in widespread regime change.

The final era outlined here is where history ends and contemporary events begin. Since the mid-200os there has been an increasing political, economic, and security institutionalization around a Moscow- and Beijing-centric orbit. Russia has attempted to re-establish itself as a regional hegemon. The Kremlin has emphasized its bilateral military and intelligence connections with former-Soviet states, promoting economic and political integration through Moscow-led organizations, as well as attempting to leverage their membership in the Chinese-led Shanghai Cooperation Organization (SCO) to manage Chinese interests in their Near Abroad (Lefebvre and McDermott 2008). In addition to the SCO, China since 2014, has pursued an economic strategic initiative, the Belt Road Initiative (BRI), that has seen massive Chinese foreign direct investments across the former Soviet-space. China's engagement with states critical to Russian security interests have undoubtedly led to unease in Moscow. What is clear in the recent history of the Sino-Russian relationship is that while both sides have made progress: normalizing and delimiting borders in the 1990s, countering U.S. hegemony, increasing bilateral trade, and promoting connectivity in Central Asia, these "successes" bely critical points of tension discussed below, that if not managed could have a destabilizing effect on the relationship's trajectory. 


\section{REVIEW OF ACADEMIC LITERATURE}

Facing an increasingly inhospitable West, Russia's "pivot to Asia” has reignited debate in the Sino-Russian relationship. Until Putin's third presidential term, most Western analyses were relatively skeptical of a mutually beneficial SinoRussian relationship due to long-held Russian strategic concerns of a rising China encroaching on Russia's Near Abroad. Most claimed that the "strategic partnership" was none more than temporary or incidental (Lo 2008). Rooted in traditional greatpower balancing, this view argued that while both countries saw increased bilateral trade and an increase in mutual connections, Moscow in the long-run would ultimately be unwilling to accept a China as an equal. Furthermore, given the Kremlin's reliance on relations with the former Soviet Union to substantiate its “Great Power” status, increasing Chinese influence in Central Asia would necessitate a strong reaction from the Kremlin. Great-power balancing underscores Russia's perennial trepidations over its perceived strategic weaknesses vis-à-vis China, primarily its expansive and underpopulated frontier. Domestically, these concerns play into growing xenophobia against Chinese-funded projects and Chinese nationals working in the Russian Far East. Importantly, while fear of outside influence and encirclement are a constant in Russia's strategic thinking, these fears are equally shared by China.

In addition, within a certain group of Russian and Chinese academics there is a strain that seems to take the often-flowery diplomatic statements at face value. Attempting to incite fears of an "Anti-American axis" on the Eurasian peninsula, this perspective has not gained much traction beyond government-funded propaganda outlets like Russia Today and China Times. What couldn't be anticipated that time was events in Ukraine that led to a rapid deterioration of relations with the West. 
Striking a balance between overly pessimistic positions on one hand and overly optimistic ones on the other, Bobo Lo, has provided a more nuanced view of Sino-Russian relations through what he described as an "Axis of Convenience”. An "Axis of Convenience" is one that "is often tactical and instrumental ... [prioritizing] expediency and opportunism...[over] an often-illusory like-mindedness” (Lo 2008). Furthermore, Lo argues though that the "asymmetry and ambivalence [of SinoRussian relations] call into question the conventional wisdom that Russia and China enjoy a bona fide strategic relationship.”

Although academic literature has failed to keep up with the fast-pace of change in this relationship, two relatively cohesive paradigms have emerged, building from the previously mentioned perspectives. While $\mathrm{Yu}-\mathrm{Shan} \mathrm{Wu}$ conveniently denominates this bifurcation as between the "doubters" and "believers" of the "robustness regime", this essay terms them as "pessimists" and "optimists".

Moving beyond the temporary partnership concept, most contemporary Western thinking falls into the pessimist camp, emphasizing that economic and political asymmetries will become a stronger driving force in the relationship, giving way to potential challenges in the long run. Contemporary pessimists understand the current partnership to be based on common regional security and economic interests, as well as countering perceived U.S. hegemony in the international order. Ambassador William Courtney in a Rand commentary, frames the issue in terms of ‘durability', asking the question, "how durable is the China-Russia 'Friendship'?” While Ambassador Courtney rules out both an all-out collapse and any form of formal alliance, he argues a more nuanced point, that uncertainties, primarily in Russia could limit bilateral engagement “...given the two nations’ differing trajectories and historical grievances" (Courtney et al 2015). It is important to note that this view does not perceive Sino-Russian engagement as simply an "Axis of 
Convenience", rather the strategic relationship has picked all of the low-hanging fruit and is beginning to confront both internal and external pressures that could stymie future developments, especially in light of a Russia’s deteriorating position. Regarding ideological convergence, Peter Baev points to increasingly incompatible perspectives of international order, especially Russia's diminutive role in China's 'evolving' concept of global order (Baev 2016). Baev argues that while both states have articulated their interests in a multi-polar order, the emerging Chinese economic and security architecture will undoubtedly challenge Russia's hegemonic role in their Near Abroad. As Russia identifies its Near Abroad as critical to its national security, any direct challenges from China would negatively impact their bilateral relationship.

"Believers" on the other hand emphasize that drivers propelling the two powers together will remain strong enough to prevent previously mentioned asymmetries from pulling it apart. This view particularly focuses in on the role of the U.S. as a driver of Sino-Russian relations (Wu 2015). From this perspective, Russian and Chinese views of U.S. policies of democracy promotion as well as the presence of U.S. troops in Afghanistan give oxygen to the relationship. While for obvious reasons Chinese policymakers play down the role of the U.S. in Sino-Russian affairs, Russian academics put a lot of weight into this dynamic. Furthermore, Russian policymakers often claim China as an equal partner, even though if political, economic, and more recently, security realities indicate otherwise.

What is clear is that the Sino-Russian relationship no longer resembles a temporary partnership based on convenience, nor is it a full-fledged alliance or ideological "Anti-American” axis. Today it is best characterized as a relatively stable strategic partnership, that sees coordination in certain areas, particularly economic, defense, and institutional development in Central Asia. However, while these are 
important pillars in the relationship, they are beginning to face increasing stresses. At this point, Russia has little room for maneuver beyond strengthening its ties with China. Russia is confronting a new Post-Cold War reality, where it is increasingly dependent on China for economic growth and as a security partner in its Near Abroad. As multiple authors have pointed out, this strategic pivot to China has not seen the level of success their mutual laudatory statements reflect (Baev 2016; Eder 2014; Eder and Huotari 2016). Analyzing these areas of coordination, it soon becomes clear that the Sino-Russian relationship has shown itself to be resilient but whether this condition will continue depends on how both sides manage increasingly asymmetrical aspects of the relationship.

\section{STRATEGIC PERCEPTIONS - DRIVERS}

As Miles Law states, "where you stand depends on where you sit”, therefore it is important to understand what factors inform Russian and Chinese decisionmakers decisions and how they perceive their position in the world. Interestingly, while both states share a common sense of insecurity in their strategic environments, there is a striking difference in how they perceive their own power and how to best wield it to achieve their foreign policy objectives.

Both Russia and China's perception of constant insecurity is steeped in long histories of foreign invasion emanating from their expansive and relatively unpopulated frontiers abutting unstable regions. On this point George Kennan in his "Long Telegram” attributes “the Kremlin's neurotic view of world affairs” to “...insecurity of a peaceful agricultural people trying to live on vast exposed plain in neighborhood of fierce nomad peoples.” The frontier regions are especially sensitive to both Moscow and Beijing due to not only their geo-strategic significance but also their potential mineral wealth. Oil and gas deposits provide both states with an 
incentive to stabilize their politically sensitive frontiers. This feeling of vulnerability serves to link real and perceived foreign threats to domestic ones. One of the key drivers of China's focus on countering terrorism, extremism, and separatism in Central Asia is due to fears from Uighur separatist movements in Xinxiang. The fear of Uighur extremists cooperating with other regional terrorist organizations across the border in Kyrgyzstan and Tajikistan is one that Beijing is particularly sensitive to (Scobell et al. 2014). China has even gone so far as to establish the Quadrilateral Cooperation and Coordination Mechanism, which is ostensibly an anti-terrorism mechanism between Afghanistan, Pakistan, and Tajikistan (Shanbazov 2016).

Beyond mutual fears of the outside, Russian strategic thinking is informed by an additional factor, its own perception as a great power (державность) (Background of Russian Foreign Policy; Mankoff 2009). Державность (great powerness) emphasizes Russia's birthright as a world power and ergo its inherent right to a sphere of influence. The collapse of the Soviet Union deeply weakened Russia's strategic position vis-à-vis its traditional sphere of interest as it faced a series of economic and political crises. Moscow faced a globalizing world that was leaving it in the dust; the U.S. became a hyperpower and China opened its doors to foreign trade. In the minds of Russian policymakers, claiming Russia as a great power acts as a remedy to soothe over a decade of humiliation. Russia often points to an outmoded "Strategic Triangle”, between the U.S., China, and Russia (Lo 2008), signifying Russia's continued belief in its position as a great power. Foreign Minister Sergey Lavrov often drives this point home, emphasizing relations between Russia and the U.S. as partners, “...we are not seeking confrontation with the U.S., or the EU or NATO. On the contrary, Russia is open to the widest possible cooperation with its Western partners (Sergey 2016). Not being seen as an equal with Washington and Beijing is deeply vexing for Moscow, as it confirms their worst fears, that 
contemporary Russia is in a terminal decline. Russia's relevance as a great power exist really only in its strategic capabilities and its toeholds in Syria and Ukraine. Russia wants to be seen as strong leader abroad, to divert attention away from failing domestic policies. Allen Lynch remarks that Putin’s strategy, “...[is] to maintain the appearance of great power status abroad while most of the sinews of Russian power have withered into evanescence at home.” As with the Soviet Union, international prestige does little to improve the daily lives of Russians scraping by in far-flung villages. Instead, the effective rhetorical use of Russia's great power status maintains Putin's grip on power and is essential for the continuation of his oligarchic regime.

While the goal of regime survival is similar to Moscow, buoyed by a thriving economy, Beijing has instead sought to cushion its rise. Preferring to 'hide its strength and bide its time', China seeks a place at the table to revise the rules of the international order and subsequently is less openly hostile, but is more opaque and insidious in its motives. As noted above, China has fervently developed multilateral institutions characterized by their reliance on Chinese capital and political will in addition to grandiose and vague strategic initiatives that besides 'raising all boats' will effectively transmute Beijing into an undisputable economic pole. There are however underlying concerns around Beijing's true intentions with their recent overtures. As an early warning of the things to come, Beijing has encouraged the use of its tightly controlled renminbi as a common currency for international transactions, as well as developing legal mechanisms in China to settle trade disputes (Daly and Rojansky 2018). A vague initiative using renminbi as an international currency, backed up by courts located in China based on its notoriously partisan legal system will cement Beijing's role in Central Asia. Furthermore, analyses on narratives and commentaries in Chinese Communist-party media suggest "[that] the BRI is less about benefitting China's partners than strengthening domestic support 
for China's Communist Party” (Daly and Rojansky 2018). As with Moscow, Beijing is correcting historical injustices and reclaiming their perceived rightful role as a global power or more concerningly for Washington, as the center of the world.

\section{BILATERAL ECONOMIC RELATIONSHIP - INCREASINGLY}

\section{ASYMMETRICAL}

Liberal trade theory argues that as the more interdependent both countries become, the likelihood of conflict between them reduces. Within that context, both China and Russia have enjoyed stable bilateral trade since the 2000s. But while on paper this booming trade appears to indicate a healthy long-term relationship, appearances can be deceiving. First, while China is Russia's largest trading partner per the Observatory of Economic Complexity (OEC), Russia is ranked in a distant ninth place on the list of China's largest trading partners. This immediate imbalance hints at a long-term trend of an asymmetrical bilateral trade relationship. Broadly this imbalance combined with Western sanctions has meant that Russia has become more and more reliant on trade with China. The other concerning development are the type of products that are being exported. The cornerstone of the Russian economy remains the export of refined petroleum products and other types of raw materials, such as iron and tin, while Russian imports from China are mostly finished products, such as electronics and automobiles (OEC 2016). The fact that Russia is seen primarily as an exporter of natural resources for China and is less vital than other Western countries, like the U.S. worries Moscow, as it confirms for Russian leadership their continued decline in international affairs (Swanström 2014).

Tensions with the EU over Ukraine and EU dependence on Russian energy, have reenergized Brussels to diversify its energy suppliers. This development combined with soft international oil prices, aging oil and gas fields, and a dearth of 
Western financing and technical expertise has led to weak economic growth and a deep recession. Moscow is especially worried about losing ground in Europe as the continent accounts for more than $60 \%$ of oil exports and around $75 \%$ of natural gas exports; both accounting for over $43 \%$ of the federal budget (Henderson and Grushevenko 2017; Barden 2017).

On paper China seems like an ideal export market for Russian oil and gas, they share a long stable border and most importantly China has an insatiable appetite for energy. While Russia exports just under a million barrels per day (bpd) of oil to China it has only recently made tepid progress with China (Barden 2017). As of 2018, two parallel pipelines bring in crude oil from fields in Eastern Siberia. Although oil has been a nascent bright spot, exports of gas has not fared as well. For decades neither side has been able to reach an agreeable price. Russia negotiates for long-term contracts charging a comparable European rate, whereas, China only wants to pay a subsidized domestic price (Eder 2014). There is a planned spur from the Gazprom-owned Power of Siberia pipeline that is expected to come online in 2019, but its long-term viability is uncertain (TASS 2017). Oil and gas pipeline negotiations only took off after Russian firms lost access to Western capital. China National Petroleum Company (CNPC) signed a series of agreements with Gazprom in 2014 on gas deliveries estimated to be worth over $\$ 400$ billion, while Chinese National Oil Companies (NOCs) and state-run banks have taken significant stakes in Russian-owned firms (Wang 2016; Paraskova 2017). The most ambitious project to date is the Yamal Liquid Natural Gas (LNG) facility, designed to export LNG to European and Asian markets via Russia's Northern Route in the Arctic Sea. Over time this project has been partially financed by CNPC and the Silk Road Fund, holding 20\% and 9.9\% of the venture respectively (Mazneva 2017). While these new energy links provide for Chinese security of supply, they highlight Russia's 
increasingly diminutive position. Russia has become more and more reliant on Chinese investment, as Russian oil and gas companies confront the challenge of maintaining export capacity from increasingly aging fields (Henderson and Grushevenko 2017). Furthermore, while China has made investments in the Russian energy market, they have simultaneously developed close energy relations with competing Central Asian states. Since 2000, China has struck favorable deals with Turkmenistan and Kazakhstan, tying both countries into long-term contracts with two separate pipelines that undercut the traditional transit route through Russia. This means that while China has invested in Russian energy, Moscow must now compete with increasingly independent Central Asian states in China's energy markets.

Beyond hydrocarbons, the Russian economy relies heavily on the defense industry inherited from the Soviet Union. Defense exports in 2016 account for over $\$ 15$ billion in revenue and comprise more than $60 \%$ of total machinery exports (Denisentsev 2017). Not just a revenue generator, the Russian defense industry plays an important role in Russian foreign policy. As with other major defense exporters, like the U.S., Russian sales abroad help expand their reach and influence into strategically vital countries. Early on China looked towards Russia to modernize its outmoded military equipment. Over time Beijing has purchased significant quantities of military hardware from Russia, from surface-to-air S-300 missile defense platforms to Su-27 fighters and even submarines (Wu 2015; Denisentsev 2017). Although Russian systems have filled critical gaps across the Chinese military, China has used the opportunity to learn from Russian designs to build its very own indigenous defense industry capable of rivaling Russia. These concerns have been realized with the production of the indigenously produced $\mathrm{J}-11 \mathrm{~B}$, an unlicensed copy of the Russian Su-27. 
As with energy, defense industry ties between Beijing and Moscow reinforce the narrative that Russia has no other choice but to cooperate with China. Even though these purchases and joint-development projects buoy the Russian defense industry, in modernizing China's military, they are tipping the strategic balance in China's favor. Furthermore, although China is an important customer of Russian systems, the question many defense experts are asking is for how long? With the help of Russian military technology, China is quickly narrowing the technical gap with Russia. Since China can produce most of the systems it used to purchase from Russian firms, Moscow has made the calculated decision to offer some of its most advanced systems, including the S-400 surface-to-air system. Knowing that Beijing will soon match Russian technical expertise in most areas, Moscow must find any leverage that it can.

\section{CENTRAL ASIA - COMPETING SPHERES OF INSTITUTIONAL DEVELOPMENT IN RUSSIA'S NEAR ABROAD}

Although there are other areas that are important to the Sino-Russian relationship, none is as prominent and as developed in both Chinese and Russian economic, political, and geostrategic thinking, as Central Asia. Central Asia is the nexus where Chinese and Russian interests are most saliently developed. The Central Asian region which is made up of the Former-Soviet republics of Kazakhstan, Kyrgyzstan, Tajikistan, Turkmenistan, and Uzbekistan, lies at the heart of SinoRussian engagement as it is considered by Russia to be a part of its "near-abroad", a crucial element of Russian national interests (Ministry of Foreign Affairs of the Russian Federation 2013). It is also of critical importance for China's ambitious economic project, the Belt Road Initiative (BRI). The land component of the BRI, linking industrious China with European markets, will do three things in theory, 
symbolically cement China's role in the region as a regional power, counteract "outside interests" in the region, and provide prosperity to the often-restive Western provinces. effectively resurrecting the Silk Road.

Both China and Russia have a shared interest in keeping Central Asia devoid of what China describes as the 'three evils': terrorism, separatism, and religious extremism (Holmquist and Norberg 2014). China’s engagement in Central Asia has been primarily through investments in the Central Asian economies in an effort to diversify energy supply and develop a trans-Eurasian bridge to Europe (Flikke and Wilhelmsen 2011; Swanström 2014). These large infrastructure projects are designed to streamline the flow of Chinese exports into Central Asian markets, Western Asia, and eventually Europe. Moreover, Chinese investment in this region has outpaced and replaced Russian investment, leaving Russia to find its unique role in the region (Olcott 2014). As the Russian economy remains stymied by serious institutional challenges most notably including corruption and overdependence on oil and gas exports, it remains unlikely that Russia will be able to engage in economic projects to the same extent as China. Instead Russia has reverted to its traditional role as the guarantor of regional security. (Flikke and Wilhelmsen 2011). Russia remains a powerful broker in military and intelligence spheres ("Russia and Intelligence Services of Central Asia"), inheriting extensive connections and a common command and control structure at the collapse of the Soviet Union. These longstanding defense and intelligence ties have been institutionalized in the CSTO. The focus of the organization is not on collective defense as with the North American Treaty Organization (NATO), instead it operates by a notion of situationally-defined collaborative defense. As the CSTO is dominated by the Russian Ministry of Defense, the organization reflects the interests and policies of the Kremlin and has little independent institutional weight (Starchak 2017). Poignantly the CSTO remains the 
only collective security organization in Central Asia, as the SCO has not developed a capacity for a defensive response beyond information sharing (Olcott 2014).

While Russia provides necessary security resources to allow for Chinese investment in the region, Russia is facing an inhospitable Europe in the West and a rising China in the South. Thus, the more isolated Russia becomes, the more dependent it is on China to maintain its long-standing foothold in Central Asia. The inevitable shift in the equilibrium towards China can be measured in the number of energy agreements that it strikes with Central Asian states, as it has with both Kazakhstan and Turkmenistan (Wilhelmsen and Flikke 2011). Energy and security represent the dualistic nature of the relationship between Beijing and Moscow as both elements have fostered closer cooperation they represent areas of future competition (Wilhelmsen and Flikke 2011). If China can diversify its energy partnerships, while developing closer defense ties with the Central Asian states, whether bilaterally or through the SCO, the Sino-Russian relationship will move away from a mutually beneficial relationship to one where Russia is a subordinate partner, a perennial nightmare for Moscow.

The development of intergovernmental institutions is another important element of this special relationship, revealing how effective both China and Russia are as partners in developing a common vision for the region. The SCO has developed into an important regional organization since its beginning in 1996. Both China and Russia have identified how significant multilateral institutions are in achieving their shared vision of a more democratic and stable international system (Carlsson, Oxenstierna, and Weissmann 2015). The SCO is unique in that it is the only regional organization in Central Asia where both China and Russia are partners. As such, it is often considered by academics as an important thermostat of Sino-Russian relations, as it lays bare the disparate interests of China and Russia. Even though the Sino- 
Russian partnership gives the organization its momentum, the organization has been largely classified as Chinese-led, as Beijing is the main financial and ideological supporter (Swanström 2014). Russia has instead preferred to develop a separate sphere of institutions, within a tight Russian orbit. In an attempt to harmonize trade and capital flows, Moscow has launched the Eurasian Economic Union (EAEU), largely modeled after the EU. However, the high tariff on outside goods including from China has Central Asian states approaching with caution.

Many analysts contend that recent multi-layered Russian integration efforts in Central Asia are in reaction to their loss of status in the region and before all trade flows to the East want to capitalize on existing Soviet infrastructure and systems (Kozyulin 2014). The Commonwealth of Independent States (CIS), CSTO, and EAEU give Russia the opportunity to engage with Central Asian states in multilateral organizations with no direct involvement from China. The lack of direct Chinese influence becomes especially critical as Chinese and Russian interests begin to diverge and as Russia becomes less useful for China in engaging Central Asian states.

Broadly, the view from Moscow towards their Near Abroad looks bleak. Russian-dominated integration projects designed to keep the former Soviet Union within Moscow's orbit have born little strategic fruit. The CIS remains largely ineffective and comatose (Kazantsev 2008). Suffering from a lacking strategic direction and uneasiness about Russian leadership, the CSTO accomplishes little beyond carrying out multilateral exercises. The glimmer of hope in maintaining a more cohesive sphere lies in the EAEU. Whether or not the EAEU can accomplish the Kremlin's hope of linking disparate and often competing former Soviet states together remains to be seen. What is clear is that vis-a-vis China, the Kremlin is bereft of options; it cannot out-invest China; it cannot pull the European or American card due to current relations with the West, nor can it unify the Central 
Asian region under its leadership. Russia is caught in-between Europe and a growing power with global ambitions, an increasing level of international criticism and economic sanctions from the West.

While publicly both Moscow and Beijing laud their strengthened partnership across a variety of different issue areas, they ignore the glaring gulf between the aspirational language and the strategic realities on the ground in Central Asia. While both states converge in the SCO little meaningful progress has been made in tying together Russia-led regional platforms with the Chinese-dominated SCO and China's other economic initiatives. The current situation in Central Asia with a rising China and a more economically and politically isolated Russia has called into question not only Russia’s position of a vis-à-vis the Central Asian states, but it has also laid bare the limits of Chinese-Russian cooperation.

\section{SECURITY AFFAIRS AND AFGHANISTAN}

The emergence of independent Central Asian states in 1991 forever altered the geo-strategic picture of Central Asia. No longer were the stans appendages of a larger imperial entity and consequently Moscow lost its protective southern underbelly. Independence ushered in the looming threat of terrorism and instability in Central Asia. These fears only intensified as Tajikistan fell into Civil War in the early-9os, fueled by a porous border with Afghanistan.

While both countries have previously stated their concerns over the future development of Afghanistan, with the heavy involvement of U.S. forces, neither showed much interest in connecting Afghanistan into their respective orbits. Instead both states seemed to prefer remaining distant and relatively disengaged from the conflict, in an attempt to keep Afghanistan relegated to a manageable 'buffer state' (Kozyulin 2014; Rydqvist and Hailin 2014). Their limited at-distance cooperation is 
exemplified by the establishment of the SCOs' Regional Anti-Terrorism Structure (SCO-RATS) in Tashkent, tasked with improving information sharing. This atdistance strategy did not last however.

While Russia remains a constant presence in Central Asian security affairs, with bases in Kazakhstan, Kyrgyzstan, and Tajikistan, China is showing an increasing interest in regional military affairs beyond the SCO. The development of the aforementioned Quadrilateral Cooperation and Coordination Mechanism between neighboring states, notably excluding Russia and India as well as increasing militarymilitary connections between China and Central Asian states indicate a potential incursion into Russia's traditional role in the region. China has provided direct military assistance to Kyrgyzstan and Tajikistan, conducted dozens of bilateral and multilateral exercises, and has fostered closer military education ties with Central Asian states (Muzalevsky 2016). In an effort to shed unneeded equipment, China has apparently proposed selling unmanned drones and other defense systems in exchange for natural gas (Muzalevsky 2016). Furthermore, China has offered significant aid to security forces in Afghanistan, including an aid package worth around $\$ 500$ million and is rumored to have built a military installation and a series of outposts across Tajikistan's border with Afghanistan (Muzalevsky 2016; Shahbazov 2016). Russia meanwhile has continued to support the Afghan armed forces as well as cooperating with India on arms transfers of Russian systems (Kugelman 2015). Russia, having already fought a war of attrition in Afghanistan and aware of the threat that extremism represents domestically, has quietly launched a series of diplomatic efforts, including offering to host talks between the Kabul government and the Taliban (Hille 2018).

While the situation in Afghanistan has stabilized for the moment, the seemingly inexorable rise of extremism undoubtedly puts pressure on China and 
Russia to further develop their security institutions to respond effectively to such potential threats. It logically follows that as both states identify extremism in Afghanistan as a common threat, a coordinated policy in Afghanistan would signify stronger mutual trust and institutional capabilities. However Beijing and Moscow seem to be pursuing separate approaches to security affairs in Central Asia and Afghanistan. Most telling, is that while China has a token information sharing center through the auspices of the SCO, it has instead preferred to pursue closer bilateral military-military relations in the region without involving Russia, going so far as to put 'boots on the ground' in Tajikistan.

\section{NORMATIVE CONVERGENCE - A COMMON WORLDVIEW?}

The final element in examining the Sino-Russian relationship is normative convergence, which takes the shape of elite restraint. Normative convergence promotes elite restraint, acting like glue, by holding together the relationship even after fissures begin to appear. These "institutions and norms induce strategic restraint and promote cooperative behavior" (Acharya 2014). Both Beijing and Moscow do share some normative convergence in their domestic regime type as well as in their foreign policies. Domestically both states have strayed from the typical Western-liberal-democratic model in pursuing a model of development that is commonly referred to as a hybrid regime (Wilhelmsen and Flikke 2011). As noted by Wilhelmsen and Flikke, both states prefer concentrated and relatively unchecked power, and “...despite very dissimilar starting points and other differences, the Chinese model of governance...ha[s] many striking similarities with the current Russian model" (Wilhelmsen and Flikke 2011).

The narrative of norm convergence is further reinforced by both China and Russia pursuing foreign policies that are focused on developing a so-called 
'democratic' international system, shaping a multipolar world order, and fostering stability through economic growth (Carlsson, Oxenstierna, and Weissmann 2015). For Moscow, the notion of fulfilling a birthright taken away after the collapse of the Soviet Union informs Russia's insistence on a multipolar system that would institutionalize Russia as pole. However, in practice, as highlighted by Pavel Baev, there are divergent understandings of global leadership. In Beijing's evolving concept of global leadership, Russia remains conspicuously absent (Baev 2016). China also operates more as an evolutionary power that is grounded firmly in the international order, whereas Russia represents more of a direct revisionist challenge to the current international order. The long-term development of the Sino-Russian relationship will largely depend how their multipolar visions are realized. For Russia's "Great Power" ambitions to be realized, it must be seen as an equal with China.

\section{CONCLUSION}

The future of the Sino-Russian relationship depends heavily on how both sides manage growing economic, political, and regional asymmetries between Moscow and Beijing. This asymmetrical dynamic is best summarized by Swanström (2014), "[that] Russia may need China more than China needs Russia and Russia's main problem in maneuvering the relationship is its competitive weakness." In the shortto medium-run it is highly unlikely that this asymmetrical relationship will significantly deteriorate. China has been diligent in managing Moscow, especially in the aftermath of Western sanctions. Beijing clearly understands that for its regional ambitions to be realized it has to appease Moscow. This cautious approach highlights their more reticent engagement with Near Abroad states on matters of defense and intelligence. Furthermore, Beijing wants to keep Moscow as a partner and has been amenable to the Kremlin's recent interest in discussing a potential EAEU-BRI free- 
trade agreement (International Crisis Group 2017). As noted previously, Moscow is in an untenable situation: "Russia has yet to fully realize that it is the most vulnerable and isolated corner in the Eurasian triangle" (Eder and Huotari 2016). Its maximalist and revisionist position vis-a-vis the West has forced the Kremlin to "go all in" with China.

It is also crucial to emphasize the important role that the U.S. and to a lesser extent the EU plays in the Sino-Russian relationship. The EU is critical to the Russian economy, as the U.S. economy is to China. Both the U.S. and EU have reacted forcibly against Russia with sanctions after Crimea and fighting in Eastern Ukraine, compelling the Kremlin to look towards China. In theory the U.S. and EU have significant economic leverage over China and Russia, however policy coordination between Washington and Brussels is highly unlikely, especially under the Trump Administration. While targeted sanctions are politically expedient in the short-term, they have deterred neither Russia nor China from deepening their mutual ties. Counterintuitively, the relationship has been strengthened in-spite of sanctions and aggressive actions by Moscow.

The first step for the Trump Administration in countering an evolving SinoRussian "strategic partnership" has already been done, in recognizing that Washington is facing an increasingly hostile international environment characterized by great power conflicts. The overarching goal of a U.S. strategy should be to counter Russian and/or Chinese dominance in Central Asia and more broadly across Eurasia. This goal recognizes the unique role that the U.S. has in the region as an outside balancing power, while also acknowledging that the U.S. does not have the wherewithal nor the intention to dominate the region itself. To accomplish this balance, the Trump Administration must engage on bilateral and multilateral 
initiatives that act to reassure traditional security partners, while providing Central Asian states with the necessary confidence to pursue independent foreign policies. In addition, the U.S., China, and Russia share a common interest in a stable and prosperous Central Asia and Afghanistan and should engage closer with China on the BRI, taking advantage of Chinese claims of its inclusivity. In this effort the Trump Administration should seek to decouple the relationship. Russia's actions targeting the heart of American democracy and their increasingly threatening strategic posture must be met with overwhelming counterforce. The Trump Administration must call out Beijing for its unfair trade practices, using the World Trade Organization dispute mechanisms and if that fails turn to tariffs and targeted financial sanctions. Finally, the U.S. must provide a strong counternarrative to Russian and Chinese state-run media, highlighting the realities of the Sino-Russian relationship. The U.S. has the facts, it just needs to present them. Above all the message is simple, disengagement from Eurasia will be at our peril. 


\section{Bibliography}

Acharya, Amitav. 2014. "Power Shift or Paradigm Shift: China's Rise and Asia's Emerging Security Order." International Studies Quarterly 58: 158-173.

Acharya, Amitav. 2014. “Thinking Theoretically About Asian IR.” In International Relations of Asia, eds. David Shambaugh and Michael Yahuda. Lanham: Rowman and Littlefield, 59-89.

Baev, Pavel K. 2016. "Russia's Pivot to China Goes Astray: the Impact on the Asia-Pacific Security Architecture." Contemporary Security Policy 37 (1): 89-110.

Barden, Justine. 2017. "Russia Exports Most of its Crude Oil Production, Mainly to Europe." https://www.eia.gov/todayinenergy/detail.php?id=33732 (Accessed January 2, 2018).

Bolt, Paul J. and Sharyl N Cross. 2010. "The Contemporary Sino-Russian Strategic Partnership: Challenges and Opportunities for the Twenty-First Century.” Asian Security 6 (3): 191-213.

Burrows, Mathew and Roger George. 2016. "Is America Ready for a Multipolar World?" The National Interest. http://nationalinterest.org/feature/america-readymultipolar-world-14964 (Accessed March 1, 2018). 
Carlsson, Märta, Susanne Oxenstierna and Mikael Weissmann. 2015. China and Russia: A Study on Cooperation, Competition, and Distrust. Stockholm: Swedish Defense Research Institute. FOI-R-4089-SE.

Courtney, William, David Sedney, Kenneth Yalowitz, and Stephen Young. 2015. “How Durable Is the China-Russia Friendship?” https://www.rand.org/blog/2015/o5/how-durable-is-the-china-russiafriendship.html (Accessed November 15, 2017).

Daly, Robert and Matthew Rojansky. 2018. "China's Global Dreams Give Its Neighbors Nightmares." Foreign Policy. http://foreignpolicy.com/2018/o3/12/chinas-globaldreams-are-giving-its-neighbors-nightmares/ (Accessed March 12, 2018).

Denisentsev, Sergey. 2017. Russia in the Global Arms Market: Stagnation in a Changing Market Landscape. Washington: Center for Strategic and International Studies.

Eder, Thomas Stephen. 2014. China-Russia Relations in Central Asia: Energy Policy, Beijing's New Assertiveness and $21^{\text {st }}$ Century Geopolitics. Wiesbaden: Springer Verlag fur Sozialwwissenschaften.

Eder, Thomas Stephen and Mikko Huotari. 2016. "Moscow's Failed Pivot to China: And How It Benefits Europe.” Foreign Affairs https://www.foreignaffairs.com/articles/china/2016-04-17/moscow-s-failedpivot-china (Accessed December 11, 2017). 
Henderson, James and Ekaterina Grushevenko. 2017. "Russian Oil Production Outlook to 2020." Energy Insight 3.

Hille, Kathrin. 2018. "Russia offers to host talks between Afghan government and Taliban.” Financial Times. https://www.ft.com/content/ba435934-fb8f-11e7-9b32d7d59aace167 (Accessed March 5, 2018).

Holmquist, Erika and Johan Norberg, eds. 2014. “Discussion.” ISAF’s Withdrawal from Afghanistan: Central Asian Perspectives on Regional Security. Stockholm: Swedish Defense Research Institute, 106-114. FOI-R-3880-SE.

International Crisis Group. 2017. “Central Asia's Silk Road Rivalries.” Europe and Central Asia Report 245.

John Rydqvist and Ye Hailin. 2014. "China, Central Asia, and the Future of Afghanistan." ISAF's Withdrawal from Afghanistan: Central Asian Perspectives on Regional Security, eds. Erika Holmquist and Johan Norberg. Stockholm: Swedish Defense Research Institute, 85-94. FOI-R-3880-SE.

Kazantsev, Andrei. 2008. "Russian Policy in Central Asia and the Caspian Sea Region." Europe-Asia Studies 60 (6): 1073-1088.

Kennan, George. 1946. Referred to as "The Long Telegram". https://nsarchive2.gwu.edu//coldwar/documents/episode-1/kennan.htm (Accessed March 1, 2018). 
Kozyulin, Vadim. 2014. "Russia and Central Asia: Relations, Opportunities and Challenges in the Light of Afghanistan Post-ISAF.” ISAF's Withdrawal from Afghanistan: Central Asian Perspectives on Regional Security, eds. Erika Holmquist and Johan Norberg. Stockholm: Swedish Defense Research Institute, 95-102. FOI-R-3880-SE.

Kugelman, Michael. 2015. “The Most Important Arms Deal You've Never Heard Of.” War on the Rocks. https://warontherocks.com/2015/12/the-most-important-arms-dealyouve-never-heard-of/ (Accessed March 5, 2018).

Lavrov, Sergey. 2016. “Историческая перспектива внешней политики” [The Historical Perspective of Russian Foreign Policy] Россия в глобальной политике [Russia In Global Affairs] http://www.globalaffairs.ru/number/Istoricheskaya-perspektivavneshnei-politiki-Rossii-18019 (Accessed October 30, 2016).

Lefebvre, Stephane and Roger N. McDermott. 2008. "Russia and the Intelligence Services of Central Asia.” International Journal of Intelligence and Counterintelligence 21 (2): 251-301.

Lo, Bobo. 2008. Axis of Convenience: Moscow, Beijing, and the New Geopolitics. Washington: Brookings Institution Press.

Lynch, Allan C. 2001. “The Realism of Russia's Foreign Policy.” Europe-Asia Studies 53 (1): 7-31 
Mazneva, Elena. 2017. "From Russia with Love: A Super-Chilled Prize for China.” Bloomberg. https://www.bloomberg.com/news/articles/2017-10-26/china-to-getfirst-yamal-lng-cargo-as-russia-says-thank-you (Accessed November 18, 2017).

Ministry of Foreign Affairs of the Russian Federation. 2013. “Концепция внешней политики Российской Федерации” [Concept of the Foreign Policy of the Russian Federation]. 303-18-02 2013.

Ministry of Foreign Affairs of the Russian Federation. 2001. “Договор о добрососедстве, дружбе и сотрудничестве между Российской Федерацией и Китайской Народной Республикой” [Treaty of Good-Neighborliness and Friendly Cooperation Between the Russian Federation and the People's Republic of China.

Muzalevsky, Roman. 2016. “China’s Long March Into Central Asia.” Stratfor. https://worldview.stratfor.com/article/chinas-long-march-central-asia (Accessed January 22, 2018).

Observatory of Economic Complexity (OEC). 2016. Country Reports. Boston: Massachusetts Institute of Technology. http://atlas.media.mit.edu/en/profile/country/ (Accessed November 15, 2016).

Olcott, Martha Brill. 2014. "Central Asia: The End of the 'Great Game'?” In International Relations of Asia, eds. David Shambaugh and Michael Yahuda. Lanham: Rowman and Littlefield, 267-292. 
Paraskova, Tsvetana. 2017. "Russia and China Continue to Boost Oil Ties.” USA Today https://www.usatoday.com/story/money/2017/10/11/russia-and-china-continueboost-oil-ties/749757001/ (Accessed January 27, 2018).

Permanent Representatives of China and the Russian Federation. 1996. "Joint Declaration by the People's Republic of China and the Russian Federation.” A/51/127.

Rozman, Gilbert. 2014. "Asia for the Asians: Why Chinese-Russian Friendship is Here to Stay.” Foreign Affairs https://www.foreignaffairs.com/articles/east-asia/2014-1029/asia-asians (Accessed November 10, 2016).

Radin, Andrew and Clint Reach. 2017. Russian Views of the International Order. Santa Monica: RAND Corporation.

Rumer, Eugene B. 2017. “Russia’s China Policy: This Bear Hug Is Real.” NBR Special Report (66). Washington: The National Bureau of Asian Research .

Scobell, Andrew, Ely Ratner and Michael Beckley. 2014. China's Strategy Toward South and Central Asia: An Empty Fortress. Santa Monica: RAND Corporation.

Shahbazov, Fuaf. 2016. “China’s Economic and Military Expansion in Tajikistan.” The Diplomat. https://thediplomat.com/2016/11/chinas-economic-and-militaryexpansion-in-tajikistan/ (Accessed March 8, 2018). 
Starchak, Maxim. 2017. "The CSTO in 2017 and How Russia Exploits its Allies.” Intersection Project http://www.intersectionproject.eu/article/security/csto-2017and-how-russia-exploits-its-allies (Accessed December 9, 2017).

Stokes, Jacob and Alexander Sullivan. 2015. “The Sino-Russo Rundown: Two Futures for Russia and China." Foreign Affairs https://www.foreignaffairs.com/articles/china/2015-08-16/sino-russo-rundown (Accessed November 10, 2016).

Swanström, Niklas. 2014. "Sino-Russian Relations at the Start of the New Millennium in Central Asia and Beyond.” Journal of Contemporary China 23 (87): 480-497.

TASS. 2017. "More than two thirds of Power of Siberia gas pipeline ready by early February.” http://tass.com/economy/988758 (Accessed February 20, 2018).

Wang, Tao. 2016. "The Great Russia-China Oil Alliance Is Here (And Why It Matters)." The National Interest http://nationalinterest.org/blog/the-buzz/the-great-russiachina-oil-alliance-here-why-it-matters-17883 (Accessed December 21, 2017).

Weissmann, Mikael. 2015. "Chinese Foreign Policy in a Global Perspective: A Responsible Reformer "Striving For Achievement." Journal of China and International Relations 3 (1): 151-166.

Wilhelmsen, Julie and Geir Flikke. 2011. "Chinese-Russian Convergence and Central Asia.” Geopolitics 16: 865-901. 
Wu, Yu-Shan. 2015. "Russia and Chinese Security." Routledge Handbook of Chinese Security, eds. Lowell Dittmer and Maochun Yu. London: Routledge, 90-103.

Ying, Fu. 2015. "How China Sees Russia: Beijing and Moscow Are Close, But Not Allies." Foreign Affairs https://www.foreignaffairs.com/articles/china/2015-12-14/howchina-sees-russia (Accessed November 1, 2016). 